\title{
CELEBRATING GLOBAL SHAKESPEARE: THE REINVENTION OF SHAKESPEARE FESTIVALS IN THE UK Isabel Guerrero
}

\author{
Universidad Isabel I / Unviversidad Internacional de La Rioja
}

\begin{abstract}
The Everybody's Shakespeare festival (1994), the Complete Works Festival (2006-2007) and the Globe to Globe (2012) are part of the tradition of celebrating Shakespeare on occasions unconnected to the author, as was also the case of the Shakespeare's Jubilee back in 1769. More significantly, the three festivals also have in common the inclusion of Shakespearean productions in languages other than English, engaging with the academic debate on global Shakespeare. By looking at the characteristics of these festivals and at the academic output they generated, the purpose of this article is to trace the evolution of Shakespeare festivals in England to convey an image of global Shakespeare.
\end{abstract}

Keywords: William Shakespeare, contemporary performance, global Shakespeare, theatre festivals.

\section{Resumen}

El festival Everybody's Shakespeare (1994), el Complete Works Festival (2006-2007) y el Globe to Globe (2012) forman parte de la tradición de celebrar a Shakespeare en ocasiones sin relación con el autor, como fue también el caso del Jubileo de Shakespeare en 1769. De manera más significativa, estos tres festivales tienen también en común la inclusión de producciones de Shakespeare en lenguas distintas al inglés, siendo así partícipes del creciente interés académico en el fenómeno denominado "global Shakespeare." Mediante el análisis de las características de estos festivales y el debate académico que generaron, este artículo busca trazar la evolución de los festivales de Shakespeare en Inglaterra para transmitir la idea de "global Shakespeare."

Palabras clave: William Shakespeare, teatro contemporáneo, global Shakespeare, festivales de teatro. 
The history of Shakespearean commemorations is usually marked by celebrations in the anniversary years, such as the centenaries of the birth or death of the playwright. This means that, at first sight, 1769, 1994, 2006 and 2012-the dates that this article explores-have nothing relevant in connection with Shakespeare. By 1769 Shakespeare had been dead for more than one hundred years; 1994, 2006 and 2012 do not coincide with any relevant birth or death anniversary of the playwright. In spite of the apparent randomness of the dates, they do hold a Shakespearean connection which is perhaps even more significant due to this randomness: they are all years in which Shakespeare has been celebrated with special events and, thanks to this, they have entered the history of Shakespeare commemorations. In 1769, Shakespeare's Jubilee, leaded by the actor David Garrick, inaugurated Shakespeare's celebrations with a series of commemorative and artistic activities in Stratford-upon-Avon. The other three dates correspond to Shakespeare theatre festivals in England in the $20^{\text {th }}$ and $21^{\text {st }}$ centuries: the Everybody's Shakespeare Festival (Barbican Centre, London, 1994), the Complete Works Festival (Royal Shakespeare Company, Stratfordupon-Avon, 2006-2007) and the Globe to Globe Festival (Shakespeare's Globe, London, 2012).

Henri Schoenmakers defines theatre festivals as events "consisting of single events, in other words: a meta-event" (28). As meta-events, theatre festivals allow for comparisons that are not possible outside the festival frame. Festivals in general, and theatre festivals in particular, are as well extraordinary meta-events which, as Alexandro Falassi notes, interrupt everyday life (74-75), giving rise to a Bakhtinian carnavalesque sense of time. This atmosphere favours the conception of theatre festivals as forms of cultural commemoration, promoting cultural identities through the presentation of a particular genre or author (Frost and Laing 108-123). Throughout history, the celebration of Shakespeare has reinforced the identity of the playwright first as local author, as was the case in the Jubilee, described by Michel Dobson as "Garrick's own dramatization of the climax of Shakespeare's investiture as national poet" (The Making of the National Poet 15), and, later, as a global author, whose dramatized apotheosis, as this article argues, can be seen in the Globe to Globe (2012).

In contrast to the Jubilee-in which Shakespeare was celebrated with parades, odes and the unveiling of a statue, among others, but not theatrical performance as such (see Deelman; England)-the Everybody's Shakespeare Festival, the Complete Works Festival, and the Globe to Globe did include the performance of Shakespeare's plays and, what is more, all of them featured productions of the canon in languages other than English. In doing so, they presented Shakespeare not only as a global author but, even more importantly, they sought to make their 
audiences consciously aware of that global feature, encouraging them to enjoy the plays in languages in which they might not have been heard before on the English stage.

Each festival had a different focus. Everybody's Shakespeare tried to offer Shakespeare's visions from all over the world. The Complete Works Festival, as its name indicates, aimed to stage all the works by William Shakespeare in the course of a year. The purpose of the Globe to Globe encompassed those of its predecessors with the staging of the complete works by international companies, getting closer than other festivals to the notion of global Shakespeare. While the dates of these festivals bear no significant relation with Shakespeare, ${ }^{1}$ they coincide with the growing academic interest in Shakespeare in places other than English-speaking countries, which means that much of the academic output that they generated engaged on the ongoing debate about global Shakespeare.

This article departs from the definition of festivals as meta-events to trace the evolution of Shakespeare festivals in England through the examples of the Everybody's Shakespeare festival (1994), the Complete Works Festival (20062007) and the Globe to Globe (2012). In order to do so, the article focuses not only on the productions invited to the festivals, but also on the narrative they create, the type of audiences they address and the challenges they pose in terms of audience reception. The analysis shows how festivals have evolved in their conception of global Shakespeare: while the Everybody's Shakespeare festival and the Complete Works Festival failed in their attempt to convey an image of a global Shakespeare due to, for instance, the selection of productions and the audiences who attended the festivals, the Globe to Globe festival overcame these limitations. In parallel to the analysis of the three festivals, the article pays attention to how the concept of global Shakespeare has grown in academia in recent years, an evolution which is actually mirrored by these three festivals.

Starting with the Everybody's Shakespeare festival, its date of 1994 is significant: it is precisely in the 90s when the growing interest in Shakespeare in places other than English-speaking countries translates into a variety of publications and conferences. Dennis Kennedy's Foreign Shakespeare had been already published in 1993, and the discussion about a European Shakespeare was already taking place in conferences as "European Shakespeares" (1990, University of Antwerp) or "Shakespeare in the New Europe" (1993, Sofia), events that would led to the foundation of the European Shakespeare Research Association (ESRA). The presence of Shakespeare in languages other than English is also

\footnotetext{
${ }^{1}$ Graham Holderness refers to festivals celebrating Shakespeare as part of national events, and not in his birthday, as the 'alternative tradition of national festivals' ("Remembrance of things past" 100).
}

The Grove. Working Papers on English Studies 24 (2017): 25-37. ISSN: 2386-5431 
acknowledged in the last chapter of Peter Holland's 1997 book English Shakespeares. The book examines productions by English-speaking companies, leaving only one chapter at the end ("Festivals and Foreigners") to look at the international companies in, precisely, the festival Everybody's Shakespeare. The festival at the Barbican Centre took place in October-November 1994, and it was described as "the first event of its kind in this country and probably the world: an international multi-disciplined celebration of the work and influence of Shakespeare" (Holderness, Cultural Shakespeare 160).

The international dimension of the festival was its key feature: it hosted nine Shakespearean productions by companies from seven countries: Georgia, the United States, Israel, Japan, Russia, France and Germany. Among the companies, the Comedie Française and the Suzuki Company of Toga stood out as landmarks of the international theatrical panorama. As mentioned above, the emphasis of the festival was on offering perspectives of Shakespeare in performance from all over the world. The official narrative of the festival deliberately pointed out to the global dimension of the author from its title (Everybody's Shakespeare, which, as Graham Holderness observes allows for two interpretations: "Shakespeare is everybody" and "Everybody is Shakespeare" [Cultural Shakespeare 160]), to the advertising campaign, featuring people from different communities and ages with a half-mask of Shakespeare's Droeshout portrait. The Barbican centre was literally taken over by the festival activities: installations, games and performances flooded its facilities. Outside the Barbican, the Shakespearemania had a counterpart on TV, with BBC2 broadcasting "Bard on the Box", including from short interludes of trivia about Elizabethan culture to full length programmes about Shakespeare. Holderness states that, because of this atmosphere of celebration, "1994 can rank with 1769 as the year of another "Great Shakespeare Jubilee" (Cultural Shakespeare 160). However, little was heard of this festival once it finished; the academic engagement with it was mostly restricted to Graham Holderness' account in his book Cultural Shakespeare. Essays in the Shakespeare Myth, and Peter Holland's analysis.

Perhaps this festival seems to have fallen into oblivion because, in spite of its effort to convey the image of a universal Shakespeare, one that belongs to everybody as the publicity campaign suggested, the perception of this Shakespeare was still that of a "foreign one", the one that Dennis Kennedy had introduced in Foreign Shakespeare in 1993. Kennedy had already noticed that, "foreign Shakespeare is more present than ever before, interrogating the idea that Shakespeare can be contained by a single tradition or by a single culture or by a single language" (16). The selection of a series of non-English speaking performances framed together in a festival challenged the idea of national 
ownership of the author, providing an opportunity to compare how Shakespeare is performed in different locations. However, many of the members of the audience would not-or could not-accept that challenge, and the festival gave rise to responses that Peter Holland (255) interpreted as xenophobic.

Attending the performances required a change in the mode of perception of English-speaking audiences and critics, who needed to shift from listening to watching Shakespeare, leaving behind the mode of reception that is thought to have been prevalent with Elizabethan audiences, for whom attending a play was almost synonymous with hearing it. As Holland points out, "Watching Shakespeare, rather than listening to Shakespeare, offered critics a means to see how a production is culturally located but few took the opportunity" (255). Another unsuccessful attempt of the festival was that of attracting diverse London communities to the Barbican. The fact that the productions presented their own cultural specificities, conveying their own messages by means of Shakespeare, served somehow to reassert Kennedy's ideas, "Perhaps the native familiarity that English-speakers assume for Shakespeare is part of a larger illusion, which might be called the myth of cultural ownership. In the end Shakespeare doesn't belong to any nation or anybody: Shakespeare is foreign to all of us" (16). The festival paralleled the interest in Shakespeare in other languages that was growing in academia, but it seems that the "myth of cultural ownership" was still in the air.

In 2005 Sonia Massai refined Kennedy's concept to posit a world-wide Shakespeare, as the label "foreign Shakespeare" has "lingering notions of English Shakespeares as a normative standard from which all other appropriations depart" (9). The following year, the RSC Complete Works Festival echoed this idea inviting eleven international companies to perform Shakespeare in their mother tongue. ${ }^{2}$ However, most of the productions were performed in English by British or American companies, twenty-three of them being produced by the RSC. The portion of the cake for foreigners was small, but the inclusion of international works legitimized the celebration of Shakespeare as the "world genius".

The Complete Works Festival was part of Michael Boyd's three-year plan when he took over the artistic directorship of the RSC. Boyd's intention was to dedicate the first year to the staging of tragedies, comedies for the second and the complete works for the third, just before closing down the Courtyard Theatre to refurbish it. As it was impossible for the RSC to stage all the works alone, some foreign companies were asked to perform their Shakespeares in Stratford. The festival, running from April 2006 until March 2007, was meant to be a unique

\footnotetext{
${ }^{2}$ For a complete list of the works in the festival performed in languages other than English visit: The Complete Works Festival 2006-7, <http://www.rsc.org.uk/about-us/history/completeworks-festival.aspx> 20 April 2015. Web source.
}

The Grove. Working Papers on English Studies 24 (2017): 25-37. ISSN: 2386-5431 
opportunity in which, as Jonathan Bate indicates, "for the first time in the company's history (perhaps in the whole history of Shakespearean production?) the complete works would be staged in the course of a year" (185).

If in the Everybody's Shakespeare festival the emphasis had been on foreign companies staging the works of the playwright, the aim of the Complete Works Festival was "to show the variety of possible approaches to Shakespeare in the theatre" (Bate 187). In fact, even the productions by the RSC showed a range of performance styles. Other festival activities included the projection of Shakespeare films on a giant screen and a kind of fringe festival, with students' productions being staged outdoors. Due to the festival atmosphere, Bate compares Stratford with Edinburgh, the festival city par excellence in the UK-"Stratford would become a festival town, a miniature Edinburgh" (155). This variety contributed to the festival atmosphere that invaded Stratford and was more remarkable than the inclusion of foreign companies.

Some of the international companies at the Complete Works Festival were the Munich Kammerspiel, staging Othello accompanied by jazz music; the South African Baxter Theatre, with Hamlet, and the Japanese Ninagawa Company, with Titus Andronicus, to mention only a few. For Michael Dobson, the inclusion of foreign companies was interesting because, "faced with ... [them] the average long-term Stratford-only theatre-goer doesn't know what to say" ("Watching the Complete Works Festival" 32). Interestingly, instead of prompting comparison with other productions, the inclusion of these companies seemed to have interrupted somehow the usual mode of reception of Stratford audiences, who lost their point of reference as they were not able to compare the productions with this or that previous staging of the RSC. As happened in 1994, the Complete Works Festival challenged again the mode of reception of British audiences. This challenge is discussed in Katherine Duncan-Jones's account of the festival for Shakespeare Quaterly (353-366), as she highlights whether the foreign productions included more or fewer lines of Shakespeare's plays, overlooking the fact that a translation is a different text while paying little attention to the cultural specificities that the performances brought to the plays.

In spite of the attempts, Everybody's Shakespeare and The Complete Works Festival did not completely succeed in their purpose to convey an image of a global Shakespeare on English festival stages. On the one hand, the critical responses to these festivals suggest that audiences were not fully prepared to make the shift from listening to watching. On the other, the inequality in terms of the quantity of productions by English and non-English speaking companies in the Complete Works Festival, together with the failure to attract audiences of diverse origin in the Everybody's Shakespeare festival, meant that an eminently English 
Shakespeare was still privileged both in terms of production and reception. Nevertheless, after the Complete Works Festival, Jonathan Bate wondered, "What will the legacy of the Complete Works Festival be? Many of the triumphs were from abroad. The most welcome aspect was the recognition that Shakespeare does not belong to the English Language and English styles alone" (4). This legacy was going to be materialised a few years after, with the World Shakespeare Festival in 2012.

The global aspect of the author was mirrored on festival stages in Great Britain's Olympic year (2012), just when the study of global Shakespeare was firmly established within Shakespeare studies thanks to contributions such as those by Dennis Kennedy, Sonia Massai, Ania Loomba, Martin Orkin or Alexa Huang. Shakespeare's presence at the Olympics was visible in many contexts: the opening ceremony included Kenneth Brannagh delivering Caliban's most famous speech from The Tempest ("Be not afeard; the isle is full of noises") as Isambard Kingdom Brunel-the famous Victorian mechanical and civil Engineer of the 19th century; the British Museum hosted a major exhibition, Shakespeare: Staging the World, the BBC broadcasted the series The Hollow Crown, and there were also six exhibitions plus 263 amateur shows all across the UK, part of the Royal Shakespeare Open Stages. ${ }^{3}$ These activities illustrate the UK alignment with Shakespeare to present the country before the whole world.

The World Shakespeare Festival, part of the 2012 Cultural Olympiad, ${ }^{4}$ aimed to stage Shakespeare's works by companies of diverse origin in several venues from 23 of April to November 2012..$^{5}$ The headline in The Guardian announcing the festival captured the spirit of the event, "Biggest Shakespeare festival ever will straddle the London Olympics. Companies from all over the world are coming to England in 2012 to join an extravaganza of Shakespeare productions" (Maev Kennedy). The "extravaganza" consisted of over 70 productions of Shakespearean productions performed on the UK stages, although The Guardian only referred to their coming to England on its headline.

As a section of the World Shakespeare Festival, the Globe to Globe Festival was held at the Globe's replica on the banks of the Thames. The Globe to Globe

\footnotetext{
3 World Shakespeare Festival 2012, <http://www.rsc.org.uk/about-us/history/worldshakespeare-festival-2012/> 17 April 2015. Web source.

${ }^{4}$ The Cultural Olympia was a programme of more of 500 cultural events in the United Kingdom held in parallel to the 2012 Olympics and Paralympics Games.

${ }^{5}$ To know more about the Shakespeare World Festival and the London 2012 Festival, in which the first was framed, see the interview with Ruth Mackenzie, the project's director, in: Simon Tait, "London 2012 Festival: Drama on Display." The Stage 8 June 2012. <http://www.thestage.co.uk/features/2012/06/london-2012-festival-drama-on-display/> 20 April 2015.
} 
staged the 37 Shakespeare's plays performed by 37 theatre companies from all around the world in their own language. These performances did not correspond to different countries, but rather to different languages-at least different variants, as some languages were used by different companies-stressing multiculturalism instead of internationalism. This might have been a deliberate choice to avoid political connotations. ${ }^{6}$ However, the festival proved that the disassociation of language and nation was extremely difficult; in the words of Alexa Huang, the "multicultural celebration of languages inevitably fuelled nationalist sentiments in various guises that ranged from political protests to celebrations of independence" ("What country, friends, is this?").

The festival provided the opportunity to explore global Shakespeare from local perspectives, adding new meanings to Shakespeare's works. The range of productions went from Henry VIII in Spanish, a Guajarati All's Well that Ends Well and even Love's Labour's Lost in British Sign Language. The festival proclaimed itself as a celebration of Shakespeare as a universal playwright. As Susan Bennett and Christie Carson note, "the nationwide World Shakespeare Festival was announced as 'a Celebration of Shakespeare as the world's playwright" (1). The claim that Shakespeare is "the world's playwright" was supported by research conducted by the RSC and the British Council that revealed that the playwright is studied by over half of the schoolchildren in the world.

Sonia Massai has observed that Shakespeare, as a world-wide author, contributes to globalization by disseminating Westernculture and presenting it as a model, a norm. The assertion of Shakespeare as "the world's playwright" and the fact that he is the most often studied and performed playwright world-wide can be, therefore, interpreted as forms of Western domination. According to Massai, Shakespeare, "has become one of the powerful global icons through which local cultural markets are progressively westernized" (4). It was not only westernization that was at play at the Globe to Globe, as the official narrative of the festival also made a statement regarding Shakespeare's ownership, with the playwright described in the official website as "coming home." As Stephen Purcell wrote for Shakespeare Survey, in the context of the 2012 events, "Whatever it is that global cultures make "Shakespeare" mean, Britain seems to be claiming that for itself" ("What country, friends, is this?" 165).

Nonetheless, the Globe to Globe Festival attempted to overcome the limitations of previous festivals regarding the global notion of Shakespeare. The context contributed to this; as Erin Sullivan points out, "Within the context of the

\footnotetext{
${ }^{6}$ Nevertheless, political issues were unavoidable. The staging of an Israeli production of The Merchant of Venice was not without controversy.
}

The Grove. Working Papers on English Studies 24 (2017): 25-37. ISSN: 2386-5431 
Olympics, an international, multilingual celebration of Shakespeare seems to have made more sense to many audience members than it would have done at any other time" (301). In this international context of the Olympics, British English language was confined to only one production, which put it in equal terms with the rest of performances meaning that, as a meta-event, the Globe to Globe was more equally designed than the Complete Works Festival. ${ }^{7}$ The comparisons that the 2012 festival prompted within the festival frame were, therefore, between productions with a different linguistic and cultural background, and not, as in the Complete Works, of a minority of productions in foreign languages against a majority of English-speaking ones. If Everybody's Shakespeare had failed to attract a varied audience, the deliberate effort of the organisers to "inspire and involve the widest and most inclusive range of UK communities" (quoted in Purcell "Shakespeare Spectatorship" 133) was successful, originating a multicultural audience in which the interaction between spectators of different backgrounds was essential for the theatrical experience.

Together with its insertion in the Olympic context, its location in London was key to the success of the Globe to Globe. The festival mirrored the global/local nature of the city with the choice of some international companies that coincided with London's communities. As a result, the festival audiences were formed by theatre-goers who did not speak the language of the production, including many critics, and those who did understand the language. Apart from the knowledge of the language and culture on the stage, audiences presented as well varying degrees of familiarity with the Shakespearean source. All this led to a need of collaboration, enhancing the collective characteristic of spectatorship. In the words of Stephen Purcell,

At the Globe to Globe, spectators who did not speak the languages or fully understand the conventions of the visiting productions seemed generally unthreatened by their own inexpert status, using the reactions and encouragement of the "in-group" spectators to assist them as they engaged with the production's system of signification. ("Shakespeare Spectatorship" 157)

Part of the success of the Globe to Globe might be accounted for by the presence in the audience of London denizens who were diasporic members of the community of the visiting company. These "local members" helped those spectators who did not understand the language to overcome the linguistic barrier.

\footnotetext{
${ }^{7}$ However, as Stephen Purcell has noticed, the fact that the English-speaking production (Henry $V$, by the Globe's resident company) did not have to endure the "constraints imposed on the other festival productions regarding running time and resources" and "was separated from the rest of the festival by a gap of three days" shows some inequalities between the "straight-English" production and the rest ("What Country, friends, is this?" 165).
} 
As in other festivals, the language barrier was patent but, this time, Englishspeaking audiences seemed eager to suppress that obstacle and turn from listening to watching Shakespeare in collaboration with the native speakers.

The role of critics was challenged by the 2012 experience too. According to Purcell, "This decentring of the critic as privileged possessor of all the codes and conventions of performance was perhaps one of the Festival's most radical sideeffects" ("Shakespeare Spectatorship" 138). The early scholarly responses to the festival (the books A Year of Shakespeare, edited by Paul Edmondson, Paul Prescott and Eric Sullivan, and Shakespeare beyond English, edited by Susan Bennett and Christie Carson) were somehow unconventional, giving rise to a narrative of the events in which the Anglo-centric perspective was abandoned thanks to the presence of academics of diverse origin, as well as of those who did not necessarily share the languages on the stage. The celebrations at the Olympics raised many questions in the field of Shakespeare studies about the global/local implications of Shakespeare in our age, how he is understood simultaneously as a global author and national poet, and what values and ideas the concept of global Shakespeare can sustain.

Through its reflection on Shakespeare's global dimension, the Globe to Globe can be understood as a product of one of the beneficial aspects of globalization, what Arjun Appadurai calls "grassroots globalisation" or "globalisation from below" (1-21), with the equal presentation of the companies contributing to overcome inequalities that capitalism has imposed, such as,-for instance, the prevalence of western artists in international festivals that claim to be showcases of international theatre. Other more problematic forces of globalization were at play in the festival, such as the sponsorship from British Petroleum (Bennett). In terms of performance, several productions were said to present commodified and pastiche visions of their localities and, on top of that, some of them had been never staged in their context of origin, were directed by foreigners, or made deliberate efforts in order to accommodate an international audience (Purcell, "What country, friends, is this?" 157). These problems, related to performing local Shakespeares for international audiences, questioned to what extent grass-roots globalization was attainable in this festival context.

Whether the festival can be seen as a form of "grass-roots globalization" or as one more sign of globalization in the negative sense of the word is a moot point. As Edward Reiss states, in the Globe to Globe "You could find here a globalized, commodified Bard, fronting a Cultural Olympiad ... or you could discover a utopian oppositional force" (231). In spite of its limitations, the festival can be credited for its attempts to embrace the notion of Shakespeare as a global author in whose work audiences and artists of different cultures can find common ground. 
When compared to the 1769 Shakespeare's Jubilee, Everybody's Shakespeare, the Complete Works Festival and the Globe to Globe do not only introduce Shakespearean productions to celebrate the playwright, but they also reinvent Shakespeare festivals in the UK with the inclusion of artists of diverse origin and, in the case of the Globe to Globe, the success to attract audiences of different backgrounds. The analysis of the three festivals indicates that there has been an evolution in the presentation of global Shakespeare in the festival context in the UK: whether the Everybody's Shakespeare and the Complete Works present international productions as the exception, rather than the norm, the Globe to Globe shows that audiences around the world usually get access to Shakespeare in different languages and theatre traditions. The festivals and their productions are also significant due to the shift in reception that they introduce for Englishspeaking audiences, who face a new type of audience reception in which the visual, and not the linguistic component, is privileged. The Everybody's Shakespeare and the Goble to Globe also attempt, with different degrees of success, something that is unprecedented in Shakespeare festivals: the inclusion of audiences of diverse origin. These festivals and the growing interest on global Shakespeare in academia demonstrate that global Shakespeare requires not only international and transnational productions of the playwright, but also audiences and scholars from all around the world.

\section{WORKS CITED}

Appadurai, Arjun. "Grasroots Globalization and Research Imagination." Globaization. Ed. Arjun Appadurai. Durhman and London: Duke University Press, 2001. 1-21.

Bate, Jonathan. "Introducing the RSC Complete Works Festival." Cahiers Élisabéthains. A Biannual Journal of English Renaissance Studies. Special issue (2007): 3-6.

Bennett, Susan and Christie Carson. Eds. Shakespeare Beyond English. Cambridge: Cambridge University Press, 2013.

Bennett, Susan. "Romeo and Juliet in Baghdad (and in Stratford, London and Qatar).” Romanian Cultural Institute, London. 15 Nov. 2014. Plenary session.

Deelman, Christian. The Great Shakespeare Jubilee. London: Michael Joseph, 1964.

Dobson, Michael. "Watching the Complete Works Festival: the RSC and its fans in 2006." Shakespeare Bulletin 25.4 (2007): 23-34. Project Muse. Web 21 Apr. 2015. <http://muse.jhu.edu/journals/shb/summary/v025/ 25.4dobson.html>. 
Dobson, Michael. The Making of the National Poet. Oxford: Clarendon Press, 2001.

Duncan-Jones, Katherine. "Complete Works, Essential Year? (All of) Shakespeare Performed." Shakespeare Quaterly 58.3 (2007): 353-366. Web. 20 Apr. 2015. <http://www.jstor.org/stable/4624994>.

Edmondson, Paul, Paul Prescott and Eric Sullivan. Eds. A Year of Shakespeare: Re-living the World Shakespeare Festival. London: Bloomsbury Arden Shakespeare, 2013.

England, Martha Winburn. Garrick's Jubilee. Columbus: Ohiato State University Press, 1964.

Falassi, Alessandro."Introduction. Carnival Ritual, and Play in Rio de Janeiro, Victor Turner." Time out of Time: Essays on the Festival. Ed. Alessandro Falassi. Albuquerque, N.M.: University of New Mexico Press, 1987. 745.

Frost, Warwick and Jennifer Laing. Commemorative Events: Memory, Identities, Conflict. London; New York: Routledge, 2013.

Holderness, Graham. "Remembrance of things past: Shakespeare 1851, 1951, 2012." Celebrating Shakespeare: Commemoration and Cultural Memory. Eds. Clara Calvo and Coppélia Kahn. Cambridge: Cambridge University Press, 2015. 78-100.

Holderness, Graham. Cultural Shakespeare. Essays in the Shakespeare Myth. Hertfordshire: University of Hertfordshire Press, 2001.

Holland, Peter. English Shakespeares: Shakespeare on the English Stage in the 1990s. Cambridge: Cambridge University Press, 1997.

Huang, Alexa. "What country, friends, is this? Multilingual Shakespeare on Festive Occasions." MIT Global Shakespeares. Web. 19 Nov. 2015. <http://globalshakespeares.mit.edu/blog/2013/01/30/what-countryfriends-is-this-multilingual-shakespeare-on-festive-occasions/>.

Huang, Alexa. Chinese Shakespeares: Two Centuries of Cultural Exchange. Columbia: Columbia University Press, 2009.

Kennedy, Dennis. Foreign Shakespeare: Contemporary Performance. Cambridge: Cambridge University Press, 1993.

Kennedy, Maev. "Biggest Shakespeare Festival ever will Straddle the London Olympics." The Guardian. Web. 6 Sept. 2011. <http://www.theguardian.com/culture/2011/sep/06/shakespeare-festivalstraddle-london-olympics?INTCMP=SRCH>.

Loomba, Ania and Martin Orkin eds. Post-Colonial Shakespeares. London and New Yyork: Routledge, 1998.

Massai, Sonia ed. World-wide Shakespeares: Local Appropriations in Film and Performance. London: Routeledge, 2005.

Purcell, Stephen. "'What country, friends, is this?': Cultural Identity and the World Shakespeare Festival." Shakespeare Survey 66 (2013): 155-65.

Purcell, Stephen. "Shakespeare Spectatorship." Shakespeare on the Global Stage. Eds. Paul Prescott and Erin Sullivan. London: Bloomsbury, 2015. 13362. 
Reiss, Edward. "Globe to Globe: 37 Plays, 37 Languages." Shakespeare Quarterly, 64.2 (2013): 220-32.

Schoenmakers, Henri. "Festivals, Theatrical Events and Communicative Interactions." Festivalising!: Theatrical Events, Politics and Culture. Eds. Temple Hauptfleisch et al. Amsterdam: Rodopi, 2007. 39-47.

Sullivan, Erin. "Olympic Shakespeare and the Idea of Legacy: Culture, Capital and the Global Future." Shakespeare on the Global Stage. Eds. Paul Prescott and Erin Sullivan. London: Bloomsbury, 2015. 283-321.

Tait, Simon. "London 2012 Festival: Drama on Display." The Stage 8 June 2012. Web. 20 Apr. 2015. <http://www.thestage.co.uk/features/2012/06/ london-2012-festival-drama-on-display/>.

The Complete Works Festival 2006-7. Web. 20 Apr. 2015. <http://www.rsc.org.uk/about-us/history/complete-works-festival.aspx>. 

